\title{
WHY ARE THE RAELIANS \\ AND OTHER NEW RELIGIOUS MOVEMENTS NOT CONSIDERED 'RELIGIONS' IN POLAND? A COMPARATIVE ANALYSIS OF THE DEFINITIONS OF RELIGION USED BY THE SUPREME ADMINISTRATIVE COURT IN THE SOCIOLOGICAL CONTEXT
}

\section{INTRODUCTION}

In 1996, at the trial of the Church of Scientology members in Lyon, the court asked sociologists of religion, namely Bryan Ronald Wilson, Karel Dobbelaere and Massimo Introvigne, whether Scientology was a religion. In the judgment, the court of appeal 'considered the arguments of the social scientists and stated that 'the Church of Scientology may claim the title of religion'. ${ }^{1}$

In 1998, the government administration and the court in Poland encountered a similar problem when the Raelians and other New Religious Movements (NRMs) decided to register their activities. In this case, deliberations were made at various levels of the executive power: the Ministry of the Interior and Administration (Ministerstwo Spraw Wewnętrznych i Adminstracji, MSWiA); and the judiciary: the Supreme Administrative Court (Naczelny Są Adminstracyjny, NSA), and it was decided that the Raelians and two other NRMs were not religions. My investigations draw on the arguments of Karel Dobbelaere and Jan Lauwers, who pointed out that:

Sociologists should not look for the essence of religion; this is a philosophical question. For them the essential aspect of religion is that it is differently defined by different categories of actors according to their position and their situational context. ${ }^{2}$

I use this as a basis for examining the use of the term 'religion' by the NSA and the administration in Poland, at the turn of the twenty-first century. The article also forms a contribution to the research in the framework of social constructionism, as promoted by James Beckford. According to this scholar, one of the goals of sociology of religion is to study 'changes in the conceptualisation

\footnotetext{
1 Introvigne (1999): 42.

2 Dobbelaere, Lauwers (1973): 546.
} 
and regulation of what counts as religion [italics in the original]. ${ }^{3}$ As the 'definition of religion, in general, is of interest only to academics and constitutional lawyers'4 I devote part of the text to a response to the question 'what is a religion?', posed by Polish scholars examining the approaches they have adopted.

The first section of this article focuses on NRMs and social reactions to them in 1989-2000. The second is intended as short presentation of the doctrines of non-registered NRMs and their attempts to register. I will also present the arguments used by the administration and the court to refuse registration. The third section provides a comparative analysis of the definitions of religion used by the NSA, and the scholarly debates on the issue. Finally, I present my own conclusions.

\section{NRMS AND SOCIAL REACTIONS TO THEM IN POLAND 1989-2000}

New Religious Movements are a relatively new phenomenon in religious history. Scholars use this term to refer to the small groups, with different beliefs, practices and organizational structure, which began to appear, from the late 1950s. Sometimes, some previously established organizations are also included. NRMs refer not only to movements that emerged in the West, for example the Children of God, but also groups which come from other cultures, such as the International Society for Krishna Consciousness (ISKCON). NRMs also include groups that refer to an occult or pagan heritage, or completely innovative organizations like Scientology. Despite the significant differences in their origins or forms of activity, they often have common elements, such as they:

tend to consist of converts; to have a membership that is atypical of the rest of the population; to have a charismatic leader; to change more rapidly and radically than older, more established religions; and to evoke fear, suspicion, and, not infrequently antagonism from non-members. ${ }^{5}$

The emergence of NRMs has triggered a series of discussions in the social sciences. In particular there was a lot of controversy about their techniques of recruitment. NRMs have been accused of brainwashing or coercive conversion charge, but most researchers have found no evidence of this. ${ }^{6}$ The activity of NRMs has also provoked lively social reactions, which took various forms: from kindly interest, to harsh antagonism and persecution. The relatives and ex-members of NRMs initiated the organizations that were set up in response to their activity, and which are known as anti-cult movements (ACMs). ACMs

\footnotetext{
${ }^{3}$ Beckford (2003): 2.

${ }^{4}$ Beckford (2003): 214.

5 Barker (2015): 805.

${ }^{6}$ Barker (1997): 61-70.
} 
were often the main source of negative media coverage of NRMs. Furthermore, they have undertaken action for institutional changes to limit their activity, seeing them as a harmful element of social life, leading to mass suicides, widespread drug use and the breakdown of family ties. ${ }^{7}$

The socio-political transformation in Eastern Europe in 1989 (and after) greatly influenced the religious landscape of Poland. Opening up to the world, the abolition of censorship, and the free movement of people and ideas, were among the many reasons that led to the rapid development of religious life. Statistically, this was manifested in the increase of newly registered religious communities. While in 1945-1989 only 36 churches and religious communities were registered, in 1990-2000 there were as many as $117 .{ }^{8}$

The changes also affected religious law. The new law of 17 May 1989 (the Law on Guarantees of the Freedom of Conscience and Religion) liberalized the registration of new religions. In order to enrol in the register, legally operating churches and religious communities had to submit an application to the MSWiA, supported by the signatures of 15 people, alongside relevant documents (such as a statute with doctrinal theses), and await a decision. Registration is not and was not compulsory for a religion to be practised, but it grants legal personality, without which it is impossible to obtain tax exemptions or the right to teach religion in schools.

The rapid growth of NRMs has not gone unnoticed by traditional churches and the mass media. The media coverage of NRMs has been far from objective, and many statements were emotionally charged. ${ }^{9}$ It influenced public opinion that became wary of NRMs, mainly treating them as sects, which in the Polish social context denotes harmful or socially disruptive organizations. Sociologists describe the atmosphere of the second half of the 1990s as a time of moral panic and conflicts related to the NRMs. This would be a result not only of the rapid growth in their numbers but also the situation of Polish society during the transition period. The fall of the Polish People's Republic and the transformation of the socio-economic system introduced a state of uncertainty and anomie, which was intensified by the rapid development of NRMs. ${ }^{10}$

This resulted in the emergence of Polish ACMs of religious and secular roots. Among the best known were the Movement for defence the Family and the Individual (Ruch Obrony Rodziny i Jednostki) which was organized mainly by the relatives of NRMs members, and the Poland-wide Committee for Defence against Sects (Ogólnopolski Komitet Obrony przed Sektami) founded by the left-wing MP Ryszard Nowak. The Roman Catholic Church has organized its own network of Information Centre on Sects and New Religious Movements in major Polish cities. ${ }^{11}$

They took various actions. From holding press conferences warning about NRMs, to parliamentary interpellations expecting measures by the State. The

\footnotetext{
7 Barker (2015): 808.

8 Bieńkuńska et al. (2019): 24.

9 Goldberger et al. (2010): 42-43.

10 Hall, Smoczyński (2010): 14.

11 Goldberger et al. (2010): 36-41.
} 
most significant change concerned the legislative branch. It was undertaken by a parliament dominated by the Left, which shows that political divisions did not affect the attitude to NRMs. In 1998, an amendment to the Law on Guarantees of the Freedom of Conscience and Religion entered into force. According to some sociologists, this change "was driven by the logic of disproportionality typical for the anti-cult discourse, which indicates the axiomatic state of moral panic.'12 It tightened the criteria for registering new religious communities. For example, it raised the required minimum number of founding members from 15 to 100 , confirmed by a public notary. While in the early 1990s all applications for registration were handled positively, after the amendment, the number of registered NRMs significantly decreased. ${ }^{13}$

From 1990 to 2000, 196 applications for registration were submitted to the MSWiA. The Ministry issued 46 decisions refusing to register, mainly for formal reasons. The possibility to appeal against this decision to the court was used in 13 cases. The NSA rejected the appeals in 10 cases and annulled the decision of the MSWiA in 3 cases. $^{14}$

\section{NRMs AND THEIR REGISTRATION ATTEMPTS}

\section{The Holy Church of Miracles National Federation of Spiritual Healers in Poland}

The first unregistered NRM, which was not recognized as a religion, was the Holy Church of Miracles National Federation of Spiritual Healers in Poland (the Church of Miracles). In documents submitted to the MSWiA, it declared that its believers 'worship the Gods and Goddesses as everyone else. They also worship the Holy Family, the Sun and the whole Universe, the Mother Earth - our Mother and all the Forces of Nature ${ }^{15}$ and that the highest aim of the Church is to

improve the world in which we live. Therefore, we should not attach too much importance to the mysteries, rites and symbols, but focus on the most important part of building culture in the broadest sense of the word, that is philosophical, political and moral culture. ${ }^{16}$

From a more practical perspective, the Church aimed at: 'healing the SPIRIT and the Body, contacting the Divine Energy on a daily basis, and preparing our members, sympathizers, and supporters to another dimension

12 Goldberger et al. (2010): 64 .

13 Bieńkuńska et al. (2019): 24.

${ }^{14}$ Calculation based on: Ministerstwo Spraw Wewnętrznych i Administracji (2000): 29; Bieńkuńska et al. (2019): 24; Wykaz decyzji odmawiających wpisu do rejestru kościołów i innych związków wyznaniowych, <http://www.macierz.org.pl/artykuly/prawa_czlowieka/wykaz_decyzji_mswia.html > [accessed 19 August 2020].

15 Pasek (2005): 84.

16 Pasek (2005): 84. 
(that is, the transition from the world of here and now to another). ${ }^{17}$ This is not a reference to the afterlife, because the Church declared: 'We want to do everything to make our Mother NATURE a paradise, and if more people will be "fulfilled" on Earth, Eden will be here and now.'18 Moreover, 'we want people to live healthily and happily here and now, not in the afterlives [capital letters in original]. ${ }^{19}$ Furthermore, the Church did not require religious loyalty from believers, as it claimed that 'our members recognize the divinity of the source from which the force is used in the healing process, but the Church of Miracles also recognizes the right of every human being to personally interpret the nature of that divinity.' ${ }^{20}$

In 1997, the Church of Miracles submitted an application to the MSWiA but it was rejected. One of the reasons for this was that it was not held to be a religious community. In this situation, the Church appealed to the NSA. The NSA upheld the decision of the MSWiA, and in its judgment stated that the Church of Miracles was not a religious community. The argument of the NSA was as follows:

In the Small Dictionary of Polish Language PWN 1994, a religious relation is defined as a set of beliefs about the structure, the purpose of human existence in relation with God. Similarly, the concept of religion is defined in the New Universal Encyclopaedia published by PWN 1994 (p. 489). According to this Encyclopaedia, religion is the relationship between man and God, in other words, the relation between man and the Sacred. It assumes the activity of the human person in the pursuit of the Sacred by approaching God. Such a doctrine is not included by the 'Church of Miracles' [...] there is no approaching through a shared religious ideology to God (Sacred) by its members. ${ }^{21}$

Another argument was the fact that its doctrine allowed each believer to belong to a different religious community of their own choice, and accept any interpretation regarding the type and nature of divinity. ${ }^{22}$ In conclusion, the NSA wrote that the Church of Miracles:

does not have any religious dogma. It focuses on the temporal goods of its members, for whom 'Eden' is supposed to be here on Earth in mortal life. [...] The main aim [...] of the community is to heal the sick with the help of bioenergy transferred by healers [...] This community has the nature of an association and not a religious community. ${ }^{23}$

\section{The Raelians}

Another unregistered NRM was that of the Polish Raelians. Its origins date back to 1973 when the inhabitants of an extraterrestrial civilization the Elohim - were said to have appeared in France to Claude Vorilhon. Ac-

\footnotetext{
17 Pasek (2005): 84.

18 Pasek (2005): 84.

19 Pasek (2005): 84.

${ }^{20}$ Pasek (2005): 85.

21 Judgment of the Supreme Administrative Court of 23 October 1998, I SA 528/98.

22 Judgment of the Supreme Administrative Court of 23 October 1998, I SA 528/98.

23 Judgment of the Supreme Administrative Court of 23 October 1998, I SA 528/98.
} 
cording to his report, the Elohim revealed that they created humankind (by genetic engineering) and initiated all religions. After this encounter, Vorilhon changed his name to Raël, and the movement he created was named the Raelian movement. ${ }^{24}$ The Raelians define themselves as the atheistic religion of the third millennium, and the continuation and fulfilment of Christianity, Islam and other religions. Their main aim is to inform humankind of the message of the Elohim and prepare people for their next coming. ${ }^{25}$ In the 1990s, the Raelians had about 40 thousand members worldwide and around a dozen members and sympathizers in Poland. ${ }^{26}$

In June 1997, they submitted an application to the MSWiA. In the official letter of 10 October 1997, the MSWiA questioned the religious character of the movement, by pointing out that the Raelians' aims and means were specific for lay associations, not religious communities. Moreover, the MSWiA called for further documentation..$^{27}$ The Raelians completed the task, but the decision of 2 February 1998 was also negative. At this level of the administrative procedure, they were unregistered, not because they were not recognized as a religious community, but as a result of their doctrine. It was considered contrary to the Polish Constitution and the laws protecting public safety, and the freedom of other people. For example, the Raelian postulate of geniocracy (global government of geniuses, people with a high IQ) ${ }^{28}$ was found to be contrary to the principles of the democratic state of law. ${ }^{29}$

In this situation, the Raelians appealed to the NSA. They pointed to the fact that in other countries they were registered and the lack of registration in Poland pushed them to the margins of society. ${ }^{30}$ The NSA rejected the Raelians' appeal, but not as a result of their doctrine's incompatibility with the law, as the MSWiA had argued. It decided that the Raelian movement was not a religion. ${ }^{31}$ The Court in judgment did not work out its own definition of religion but used the lexical definition to which it referred in the case of the Church of Miracles: religion was defined as a human relationship with God (the sacred). The NSA did not find this relationship in the Raelian beliefs:

'the commandments' or recommendations made to members of the Raelian movement had little in common with those issues that characterize the religious community. It really shows that the doctrine of the Raelian Movement corresponds to the program of a political party or associations, not to the doctrine of a religious community. ${ }^{32}$

The new element, in this case, was referring to the definition of 'atheism' in the Polish Language Dictionary of 1978. Its use was probably the result of

\footnotetext{
${ }^{24}$ Polski Ruch Raeliański (1997a).

25 Polski Ruch Raeliański (1997b).

${ }^{26}$ Beźnic (1997): 330.

${ }_{27}$ Judgment of the Supreme Administrative Court of 22 January 1999, I SA 775/98.

28 Chryssides (2006): 510.

${ }^{29}$ Mikulska (2002): 43.

30 Judgment of the Supreme Administrative Court of 22 January 1999, I SA 775/98.

31 Judgment of the Supreme Administrative Court of 22 January 1999, I SA 775/98.

32 Judgment of the Supreme Administrative Court of 22 January 1999, I SA 775/98.
} 
the self-declaration of the Raelians as an atheistic religion. In the perspective of the NSA, it was difficult to associate atheism, which is a view denying the existence of God'33 with religion, which 'is the relationship between man and God. It assumes the activity of the human person in the pursuit of the sacred by approaching God. Therefore it is hard to talk about the Raelian religion. ${ }^{34}$ Since the Raelians also declared that they were the successors to the great world religions (Christianity, Islam), the NSA asked a rhetorical question: "To what extent does "the atheist Raelian religion" - which denies the existence of God - continue, for example, the Christian religions, which just assume the existence of God.' 35

\section{The Order of Initiated Knighthood of the Lineage of the Spiral Ring of Entathmiadormia}

The Order of Initiated Knighthood of the Lineage of the Spiral Ring of Entathmiadormia (the Order) referred to the tradition of esoteric pantheistic orders. In doctrine submitted to the MSWiA, it was stated that

The universe is an impersonal Being, which is the Creator of all existence and activity. It covers all space and time. [...] The Universe - Great, Everlasting and Infinite Intelligence created as its present forms the existence of a series of interpenetrating elements from which man can experience the existence of three: the Universe of Matter, the Universe of Energy and the Universe of the Immaterial. ${ }^{36}$

The Order did not gain permission from the MSWiA to enrol in the register. Among other things, the officials stated that there was no ground for recognizing it as a religion. Thus, the Order appealed to the NSA, insisting that it is a religion and that the MSWiA has no competence to judge over what is a religion and what is not. Furthermore, the Order pointed out that there is no definition of religion under Polish law. In this case, the NSA partially accepted the Order's arguments.

The court sustained that the MSWiA had the right to recognize whether a community had a religious character or not. Nevertheless, it acknowledged that 'in fact, in Polish law the concept of religion has not been defined.' ${ }^{37}$ The NSA also remarked that in modern science there is lack of 'the only universally accepted definition of religion'38 and referred to a new source: The Universal Encyclopaedia PWN from 1967. According to this, there are two approaches to the interpretation of religious phenomena. The first

\footnotetext{
33 Judgment of the Supreme Administrative Court of 22 January 1999, I SA 775/98.

34 Judgment of the Supreme Administrative Court of 22 January 1999, I SA 775/98.

35 Judgment of the Supreme Administrative Court of 22 January 1999, I SA 775/98.

${ }^{36}$ Zakon Wtajemniczonego Rycerstwa Linii Spiralnego Pierścienia - Entathmiadormia

37 Judgment of the Supreme Administrative Court of 7 May 1999, I SA 1387/98.

38 Judgment of the Supreme Administrative Court of 7 May 1999, I SA 1387/98.
} (1998a): 1 . 
recognizes the specific and common element of all religions in man's relation to the 'sacred'. In the various religions, this value is differently understood: in monotheistic [religions], it is the identification with God, in polytheistic ones, with the Pantheon; in other religions with moral, social or impersonal power. ${ }^{39}$

The second approach is that 'religious phenomena are interpreted as a functional reference to values and needs, which in themselves do not have religious character and consider religions as a form, expression or a substitute for the realization of these values and needs. ${ }^{40}$

In the absence of a definition of religion under Polish law, and given the different approaches adopted in science, the NSA annulled the MSWiA's decision and acknowledged that

the full assessment of the character of the community - in the face of doubts of its religious character [...] can only be made after completion of the proceedings by experts. Knowledge in the field of religious studies - as having a special character - requires the appointment of an expert. ${ }^{41}$

Put briefly, to decide whether an NRM was a religion or not, scholarly expertise was needed. Due to changes in the law, the Order had to submit a new application for registration which was rejected on a formality. Thus, the MSWiA did not have to commission an enquiry that warranted religious studies expertise. ${ }^{42}$

\section{ANALYSIS OF THE DEFINITIONS OF RELIGION USED BY THE NSA AND SCHOLARLY DEBATES AROUND THEM}

\section{The sociological characteristics of the definitions used by the NSA}

In the sociology of religion, different ways of defining religion can be distinguished, but two views appear to be crucial. ${ }^{43}$ The first contains definitions that can be described as functional, because they come from the definition of specific functions, for example, social integration or making sense of suffering. In this way, a given social institution is classified as religious or not.

A classic example is John Milton Yinger's definition, 'Religion [...] can be defined as a system of beliefs and practices by means of which a group of people struggle with the ultimate problems of human life. ${ }^{14}$ Similarly, functionality is the basis of Clifford Geertz's anthropological definition of religion as 'a sys-

\footnotetext{
39 Judgment of the Supreme Administrative Court of 7 May 1999, I SA 1387/98.

40 Judgment of the Supreme Administrative Court of 7 May 1999, I SA 1387/98.

${ }^{41}$ Judgment of the Supreme Administrative Court of 7 May 1999, I SA 1387/98.

${ }^{42}$ The attempt at registration of Pastafarians in 2012 marked the first appearance of experts. However, due to the appearance in the different context, it should be described in a separate text.

${ }^{43}$ The literature on this subject is enormous. See for example Mcguire (2002): 8-15.

${ }^{44}$ Yinger (1970): 7.
} 
tem of symbols [...] formulating conceptions of a general order of existence', ${ }^{45}$ or Thomas Luckmann's vision of religion as a tool to 'the transcendence of biological nature.' ${ }^{46}$ The disadvantages of functional definitions (although favoured among sociologists) are their incompatibility with the popular intuitive definitions of religion. Furthermore, they are too broad, because they can include such phenomena as the American civil religion or ideological systems, like communism. Moreover, it is difficult to talk about 'functional alternatives' to religion within this framework. ${ }^{47}$

The second way is known as substantive. It states what religion is and attempts to discover its essence, which is mostly defined as the relationship to God, the sacred and the supernatural. An example is Peter L. Berger's definition: '[r]eligion is the human enterprise to which a sacred cosmos is established', ${ }^{48}$ or more recently Steve Bruce's: '[r]eligion [...], consists of beliefs, actions and institutions which assume the co-existence of supernatural entities with powers of action, or impersonal powers or processes possessed of moral purpose [italics in the original].' ${ }^{\prime 9}$ The weakness of substantive definitions lies in their over-dependence on subjective, non-verifiable philosophical and theological concepts, as well as intense, unconscious cultural conditioning. In this case, there may be problems with non-theistic religions, such as Buddhism.

In the above-presented cases, it is clear on which sociological definition of religion the NSA decisions were based. By adopting the definitions of religion contained in the encyclopaedias and dictionaries, referring to the concept of faith in God and the sacred, they undoubtedly championed a substantive definition of religion. Only in the case of the Order did the NSA acknowledge that religion could also be defined functionally. It is worth noting that the judges in Poland, unlike judges in the USA, did not attempt to create their own definitions of religion. ${ }^{50}$

Looking further at the definitions used by the NSA, it is necessary to emphasize their cultural context. Günter Keher remarked that in the Christian culture, the term religion '[m]eans a system of beliefs containing statements about God and the world which is supported by a certain organization and with which the identification is exclusive. ${ }^{51}$ In the Polish case, this model of religion is undoubtedly that of the Roman Catholic Church. An NRM which differs significantly from this model will not be recognized as a religion. Proof of such an approach can be the NSA's judgment on the Church of Miracles. The NSA decided that it did not deserve to be recognized as a religion, since each of its members may at the same time belong to another religion of their choice. A similar case was encountered by the Raelians, who considered their

\footnotetext{
${ }^{45}$ Geertz (1966): 4.

46 Luckmann (1967): 49.

47 Dobbelaere, Lauwers (1973): 540.

48 Berger (1973): 34.

49 Bruce (2011): 112.

50 Donovan (1995).

${ }^{51}$ Kehrer (1997): 20.
} 
religion as atheistic. By denying the existence of God, they find themselves automatically outside the scope of the definition of religion used by the NSA.

From a sociological perspective, the definition of religion adopted by the NSA in Poland was a substantive definition, firmly anchored in the Judaeo-Christian cultural context. It consisted of the theistic image of God and the belief in the necessity of being loyal to one God. A question may be raised as to what caused the application of such a definition. There are three reasons for this.

Firstly, substantive definitions allow for the precise separation of different spheres of social life. State activity must also be based on such divisions. The administration always seeks clarity in its views. Hence, the state will prefer substantive definitions, clearly separating the religious from the non-religious.

Secondly, the NSA judges live and work within the Polish socio-cultural context, where the Roman Catholic Church is the model of religion. If a new community is similar to the Catholic Church, for example in doctrine or forms of worship, it has a much better chance of being recognized as a religion by society and legal registration. Furthermore, Polish society is one where the processes of secularization are minimal. ${ }^{52}$ The definition of religion in a secularized society varies from its definition in a religious society. In the former case, religion is widely treated as an available source of symbols. In the latter, as in Poland, religion is an institution that is taken-for-granted. ${ }^{53}$

Thirdly, the decisions of the MSWiA were probably influenced by the negative public attitude towards NRMs. This is evidenced by the fact that within the first four years of the new religious law (1990-1993), all applications for registration of NRMs were handled positively. When the law was amended in 1998, the number of registered religious communities significantly decreased.

In the case of the NSA judgements, the question of how they were affected by the then negative social reaction to NRMs is not easy to identify. Indeed, judgments do not occur in a social vacuum and in isolation from the prevailing public moods. Nevertheless, it seems that the socio-cultural context with the Roman Catholic Church as the model of religion was more important than moral panic over NRMs. This thesis can be supported by the lack in the NSA's justifications of allegations of brainwashing or the destruction of family ties, which are popular in ACM discourse.

It can be concluded that the NSA judgments were inconsistent. ${ }^{54}$ In two cases, the court itself decided whether the group was a religion or not. In one case, it stated that it scholarly expertise is needed. However, it is difficult to deduce from this inconsistency that the court succumbed to moral panic. It can even be argued that the case of the Raelians, who were not recognized as a religion, and provoked a debate, influenced the NSA next judgment. In it the court declared that in such a complicated matter as defining a religion, it is necessary to refer to religious studies scholar. It was an important move

\footnotetext{
52 Borowik (2017).

53 Beckford (1999).

${ }^{54}$ Mikulska (2002): 46.
} 
towards expert knowledge and going beyond the social moods prevalent at the time.

Scholars dealing with NRMs also interpreted the NSA judgements in terms of ignorance rather than pressure from public opinion or the media. ${ }^{55}$ Moreover, other courts in Poland issued verdicts in favour of NRMs at the time when conflicts over them have intensified. Examples are the slander cases brought by the Chaitanya Mission or ISKCON against those who spread false information about them. ${ }^{56}$ The courts were based solely on the facts and Polish law, not on allegations made by ACMs.

\section{The scholarly debate about definitions of religion used by the NSA: between social criticism and social constructionism}

The problem that became apparent along with the judgments of the NSA was also noticed among scholars. Two positions were clearly presented, which can be called critical and constructionist.

The first was presented by Zbigniew Pasek, a religious studies scholar. He analysed the definition of religion used by the NSA, against the background of other scholars' definitions, such as the definitions of Cornelius Petrus Tiele and Nathan Olaf Söderblom, Jacques Waardenburg, and functional definitions. ${ }^{57}$ He reached the unambiguous conclusion that the courts had adopted a narrow and archaic definition of religion. ${ }^{58}$ As Pasek has noted, the use of substantial definitions and the non-registration of some NRMs has negative social effects, because 'The number of those who feel hurt by the state authorities is increasing. ${ }^{59}$ Moreover, he stated that allowing the authorities to decide what is a religion and what is not, and to assess the principles of faith in religious communities, amounts to interference, which is not only a 'manifestation of administrative licensing of privileges' ${ }^{60}$ but can be treated 'as a manifestation of intolerance.' 61 The solution to the problem would be to refer to expert knowledge. Specialists should decide what is and what is not a religion. The weakness of Pasek's proposal is the lack of any justification as to why the definition of religion developed by scholars must be more decisive than the understanding of religion by an ordinary person from the street, or the officials of recognized religious organizations.

Another position was taken by Włodzimierz Pawluczuk, a sociologist. He agreed with a broad definition of religion and what was proposed by Pasek. Nevertheless, he strongly emphasized that the sociologist as a person is involved in a particular worldview and a certain ideology and expresses it,

\footnotetext{
${ }^{55}$ Pasek (2000): 37.

56 Mikulska (2002): 68-69.

57 Pasek (2000).

${ }^{58}$ Pasek (2000): 38.

59 Pasek (2000): 37.

60 Pasek (2005): 87.

61 Pasek (2005): 86.
} 
among others, in defining religion. ${ }^{92}$ As these limitations cannot be crossed, Pawluczuk proposed his own definition of religion: 'Religion is what people have called religion.' ${ }^{63}$ Thus, his approach can be classified as social constructionism.

Pawluczuk had no illusions that the Polish courts would adopt a broad, functional definition of religion. His view was based on popular opinion, where the object of religious worship is perceived to be decent and transcendent. This is why a religion, whose object of worship comes from this world, for example power, sport or sex, will never be recognized by society as a full-fledged, decent religion. It can fulfil some of the functions of religion, but by omitting the transcendent element and by focusing on what is immanent it will remain incomplete in the Polish socio-cultural context. For Pawluczuk, the essence of defining religion does not lie in reaching any ultimate truth, to which, according to Pasek, scientists can have access, but rather in 'questioning the social contract $^{\prime 64}$ or the historical and political process. Depending on whether Poland will remain a country with a strong Catholic identity or will meet the fate of secularized Western societies, in which invisible private religions prevail, such a definition of religion will dominate..$^{65}$

Referring to the above positions, it seems Pawluczuk's approach is more balanced and convincing. The primary function of the courts is to settle disputes, in a particular area and a particular time, and it is not necessary to apply the universal, wide definitions of phenomena. The conviction that such definitions, especially of such complex social phenomenon as religion, exist and should be applied universally is a kind of positivist utopia. The history of the Church of Scientology in England can prove this. In 1970 it was not recognized as a religion. Nevertheless, by 2013 the situation had changed and Scientology was registered. As Lord Toulson stated, this was caused by 'developments in the common understanding of the concept of religion due to cultural changes in society'. ${ }^{66}$ Thus, registration was not the result of changes in dictionaries, but rather the consequence of social transformation in England.

Pasek does not account for why the Polish courts, which are operating in a completely different social context than, for example, the English courts, should adopt a definition of religion which is used in secularised multi-ethnic societies.

Top-down changes made by the judiciary could weaken its authority. If a court recognized as a religion something that "people have not called a religion', for example, the belief in UFOs, it might lead to criticism not only from ACMs but also from broader public opinion, as was the case in France with the case of Scientology. ${ }^{67}$

${ }^{62}$ Pawluczuk (2002): 123.

63 Pawluczuk (2002): 126.

64 Pawluczuk (2002): 128.

${ }^{65}$ Pawluczuk (2002): 128.

${ }^{66} R$ (on the application of Hodkin) $v$ Registrar General of Births, Deaths and Marriages [2013] UKSC 77 para 34.

${ }^{67}$ Introvigne (1999): 42. 
In this situation, it seems better to use local definitions of social phenomena, including religion, than just considering them outdated and incompatible with the latest scientific knowledge. In social life, it is safer to wait for grassroots socio-cultural changes, which, as in the case of other countries, lead in practice to an institutional change of what is considered a religion. Pawluczuk's seemingly tautological definition, that 'religion is what people have called a religion', is a better proposal from the social practice perspective. It can be interpreted as a position that rejects the definitions of religion created only by experts in favour of local, contextual definitions.

These researchers' approaches show that the key difference lies in reference to the social concepts that define religion. According to Pasek, the NSA should only be based on the latest expert knowledge. In contrast, Pawluczuk claims the court will take into account collective social concepts because judges always act in a particular political and historical context. From this perspective, the role of the court is to negotiate the meanings between local and scientific knowledge.

\section{CONCLUSIONS}

Analysing the use of definitions of religion employed by the administration and the court, the following essential characteristics can be distinguished:

1. The Polish administration and the court did not formulate their own definition of religion, as courts in the United States have done. Furthermore, in the NSA's justifications, there were no objections to NRMs in terms of psycho-manipulation or criminal activity. Such objections are frequently used in the public discourse in order to prove that some NRMs are not religions. ${ }^{68}$

2. The NSA used the narrow substantive definitions of religion contained in popular encyclopaedias and dictionaries.

3. Apart from substantive definitions, there are elements inherited from the Judaeo-Christian tradition: religion is a belief in God, requiring loyal believers. According to this way of thinking, the 'atheistic religion' of the Raelians is an apparent oxymoron.

4. The choice of such definition of religion was influenced by public opinion, which was wary of NRMs and the social context of understanding religion. Polish society is not secularized and defines religion differently than secularized Western society.

5. In subsequent cases considered by the NSA, objections appeared as regards the definition of religion employed. Whereas in the case of the Church of Miracles or the Raelians, the NSA had no doubt that they were not religions, in the case of the Order doubts were raised. This led the court to make a recommendation to the administration: to appeal to expert knowledge when a specific NRM request was deliberated.

68 Introvigne (1999): 51-65. 
6. Analysing the scholarly debate, two approaches can be distinguished: the first, which recognizes that the definition of religion used by the NSA is outdated and discriminatory, and that, instead, it should be based on expert knowledge; and the second, which is based on social constructionism, and concludes that religion is what people recognize as religion. In this approach, the object worshipped can only be a decent and transcendent thing. The future definition of religion in Poland is expected to be somewhat the result of a social contract and historical processes, rather than the discovery of universal truth by scholars. Thus the role of the judges will be to negotiate meanings between local and scientific knowledge.

Maciej Krzywosz

University of Biatystok

maciej@uwb.edu.pl

https://orcid.org/0000-0001-6524-6288

Barker, E. (2015). New religious movements, [in:] J.D. Wright (ed.), International Encyclopedia of the Social \& Behavioral Sciences. Second edition. Vol. 16. Amsterdam: 805-808.

Barker, E. (1997). Nowe ruchy religijne. Tłum. T. Kunz. Cracow.

Beckford, J.A. (1999). The politics of defining religion in secular society: from a taken-for-granted institution to a contested resource, [in:] J.G. Platvoet, A.L. Molendijk (eds.), The Pragmatics of Defining Religion: Contexts, Concepts and Contests. Leiden: 23-40.

Beckford, J.A. (2003). Social Theory and Religion. Cambridge.

Berger, P.L. (1973). The Social Reality of Religion. Harmondsworth.

Beźnic, S. (1997). Przegląd nowych ruchów religijnych w Polsce, [in:] E. Barker, Nowe ruchy religijne. Tłum. T. Kunz.Cracow: 251-339.

Bieńkuńska, A., Ciecielag, P., Góralczyk, A., Gudaszewski, G., Piasecki, T., Ks. Sadłoń, W. (2019). Wyznania religijne w Polsce w latach 2015-2018. Warsaw.

Borowik, I. (2017). Religion in Poland between tradition and modernity, or religious continuity and change in conditions of transformation, [in:] S. Ramet, I. Borowik (eds.), Religion, Politics, and Values in Poland: Continuity and Change Since 1989. New York: 185-208.

Bruce, S. (2011). Defining religion: a practical response. International Review of Sociology Revue Internationale de Sociologie 21(1): 107-120.

Chryssides, G. (2006). Raëlian Church, [in:] P.B. Clarke (ed.), Encyclopedia of New Religious Movements. London: 509-511.

Dobbelaere, K., Lauwers, J. (1973). Definition of religion - a sociological critique. Social Compass 20(4): 535-551.

Donovan, J.M. (1995). God is as God does: law, anthropology, and the definition of 'religion'. Seton Hall Constitutional Law Journal 6(1): 23-99.

Geertz, C. (1966). Religion as a cultural system, [in:] M. Banton (ed.), Anthropological Approaches to the Study of Religion. London: 1-46.

Goldberger, G., Hall, D., Grešková, L., Smoczyński, R. (2010). Societal reactions to new religious movements in Poland, Croatia and Slovakia, [in:] D. Hall, R. Smoczyński (eds.), New Religious Movements and Conflict in Selected Countries of Central Europe. Warsaw: 29-94.

Hall, D., Smoczyński, R. (2010). Introduction, [in:] D. Hall, R. Smoczyński (eds.), New Religious Movements and Conflict in Selected Countries of Central Europe. Warsaw: 7-28.

Introvigne, M. (1999). Religion as claim: social and legal controversies, [in:] J.G. Platvoet, A.L. Molendijk (eds.), The Pragmatics of Defining Religion: Contexts, Concepts and Contests. Leiden: 41-72.

Kehrer, G. (1997). Wprowadzenie do socjologii religii. Tłum. J. Piegza. Cracow.

Luckmann, T. (1967). The Invisible Religion: The Problem of Religion in Modern Society. New York. 
Mcguire, M.B. (2002). Religion: The Social Context. Belmont, CA.

Mikulska, A. (2002). Wolność sumienia i wyznania: Raport z monitoringu. Warsaw.

Ministerstwo Spraw Wewnętrznych i Administracji, Międzyresortowy Zespół do spraw Nowych Ruchów Religijnych (2000). Raport o niektórych zjawiskach związanych z działalnością sekt w Polsce. Warsaw.

Pasek, Z. (2000). Problem definicji religii a nowe ruchy religijne: uwagi na podstawie sytuacji współczesnej Polski. Nomos 30/31: 27-38.

Pasek, Z. (2005). Ugrupowania religijnego pogranicza, [in:] W. Nowak, S. Ropiak (eds.), Sekty jako wyzwanie społeczne i religijne. Olsztyn: 79-88.

Pawluczuk, W. (2002). Socjologia pojęcia "religia", [in:] M. Karas (ed.), Definicja religii. Studia i szkice. Cracow: $123-128$.

Polski Ruch Raeliański (1997a). Podstawowe założenia doktrynalne [Basic Doctrine Theses]. Unpublished. Submitted to the MSWiA.

Polski Ruch Raeliański (1997b). Uzupełnienie podstawowych założeń doktrynalnych [Supplementary Basic Doctrine Theses]. Unpublished. Submitted to the MSWiA.

Yinger, M.J. (1970). The Scientific Study of Religion. New York.

Zakon Wtajemniczonego Rycerstwa Linii Spiralnego Pierścienia - Entathmiadormia (1998a). Tezy Doktrynalne Entathmiadormii [Doctrine Theses of Entathmiadormia]. Unpublished. Submitted to the MSWiA.

\section{WHY ARE THE RAELIANS AND OTHER NEW RELIGIOUS MOVEMENTS NOT CONSIDERED ‘RELIGIONS’ IN POLAND? A COMPARATIVE ANALYSIS OF THE DEFINITIONS OF RELIGION USED BY THE SUPREME ADMINISTRATIVE COURT IN THE SOCIOLOGICAL CONTEXT}

\section{Sum mary}

In 1980, in Poland, there were about 30 religious minorities. The socio-political transformation changed the religious landscape dramatically. In 1999, there were already 155 . Not all new religions, however, were registered. In the case of the Church of Miracles, the Raelians, and the Order of Initiated Knighthood, registration was refused. The Ministry of the Interior and the Supreme Administrative Court decided that they did not fulfil the requirements of a 'religion'. The purpose of this article is to examine, from a sociological perspective, the definitions of religion used by the court, by which the above new religious movements were not recognized as religions. The analysis shows that the court and administration ruled on the basis of substantial definitions of religion, reducing religion to believing in God or the sacred. Furthermore, the article presents the socio-cultural reasons behind the choice of such definitions, and reviews the scholarly debate on the issue.

Keywords: sociological definition of religion; legal definition of religion; new religious movements in Poland; law and new religions; the Raelians 


\section{INFORMACJE DLA AUTORÓW}

1. Objętość nadsyłanych tekstów nie może przekraczać 1 ark. wyd. (36-40 tys. znaków wraz ze spacjami i przypisami) w wypadku artykułu. Obliczając objętość tekstu, należy wziąć pod uwagę, że obejmuje ona również wykaz cytowanej literatury, a także tabele i ryciny. Objętość recenzji nie powinna przekraczać 10 tys. znaków.

2. Zgłaszany tekst powinien być zanonimizowany $-\mathrm{z}$ tekstu głównego i przypisów, a także z metadanych pliku należy usunąć wszelkie informacje pozwalające zidentyfikować autora/autorów (np. o grantach).

3. W zgłoszeniu należy podać dane o autorze/autorach, adres do korespondencji, numery telefonów i adres służbowej (instytucjonalnej) poczty elektronicznej, a także identyfikator ORCID. W wypadku pracowników naukowych prosimy także o podanie nazwy i adresu uczelni macierzystej.

4. Teksty należy przesyłać za pośrednictwem platformy elektronicznej: https://pressto.amu.edu.pl/index.php/rpeis/about/submissions.

5. Wszelkie tabele, wykresy lub ryciny będące częścią tekstu należy również przesyłać w formie edytowalnego zapisu elektronicznego. Minimalna grubość linii rysunku powinna wynosić $0,4 \mathrm{pkt}$, a rysunki należy sporządzić w wersji czarno-białej, w formacie nie większym niż format kolumny $(126 \times 180 \mathrm{~mm})$.

6. Do artykułu należy dołączyć krótkie streszczenia (abstrakty) w języku polskim i angielskim (ok. 1,5 tys. znaków) oraz słowa kluczowe.

7. Do przesłanej propozycji publikacji należy dołączyć oświadczenie (dostępne na: www.rpeis.pl). Po przyjęciu tekstu do druku autor podpisuje umowę wydawniczą z czasopismem.

8. Termin wykonania korekty autorskiej wynosi maksymalnie 1 tydzień. Po upływie tego terminu tekst kierujemy do publikacji wyłącznie z korekta redakcyjna.

9. Zgłoszenie artykułu, proces recenzyjny oraz publikacja w RPEiS są bezpłatne.

10. Publikacja w RPEiS oznacza zgodę na zdeponowanie tekstu w wersji elektronicznej w repozytoriach, bazach i na platformach indeksujacych i upowszechniających treści naukowe.

Szczegółowe zasady edytorskie dostępne na www.rpeis.pl 


\section{SUBMISSION GUIDELINES}

1. The length of manuscripts submitted to RPEiS must not exceed 36,00040,000 characters (6,000 words), including spacing and footnotes, reference list, and tables and figures, in the case of articles, and a maximum of 10,000 characters (1,500 words) for reviews.

2 . The submitted text should be anonymized - any information making it possible to identify the author(s) (for example, concerning grants) should be removed from the main text and footnotes, as well as from the file metadata.

3. The author's personal details, correspondence address, telephone numbers and institutional email address as well as ORCID identifier must be attached. In the case of academic staff, we also request the name and address of their university.

4. Manuscripts should be submitted via https://pressto.amu.edu.pl/index. php/rpeis/about/submissions.

5. All tables, graphs or graphics in the body of the text must be sent in enable-editing electronic form. The minimum line width should be $0.4 \mathrm{pts}$ and figures should be in black and white, in a form that does not exceed the format of a $128 \times 180 \mathrm{~mm}$ column.

6. A short abstract, in Polish and English, must be attached (1,500 characters/ 250 words) with a list of keywords.

7. A declaration must be attached to the application for publication (available at www.rpeis.amu.edu.pl). After the text has been accepted for publication, the author will sign a publishing agreement with the journal.

8. The deadline for authors' revisions is one week. Thereafter the manuscript will be sent for publication with the editors' revisions only.

9. There are no fees for submitting, processing or publishing an article in RPEiS.

10. Publication in RPEiS implies that the author consents to the electronic location of the text in repositories, databases and platforms indexing and disseminating scientific content.

More on editorial principles at www.rpeis.pl 
